\title{
A IMPORTÂNCIA DA ESCRITA DA LÍNGUA PORTUGUESA PARA A LÍNGUA INY
}

Manaijè Karajá ${ }^{1}$

\section{RESUMO}

O presente texto aborda as experiências interculturais adquiridas nas aulas de redação em língua portuguesa na aldeia Hawalò, da etnia Karajá. Refletimos, então, sobre a necessidade do ensino da escrita em língua portuguesa e como esse conhecimento deve ser acompanhado por práticas interculturais que garantem, também, a consciência da importância da língua materna.

PALAVRAS-CHAVE: Escrita em língua portuguesa. Língua Karajá/Iny. Ensino intercultural.

\section{ABSTRACT}

This text deals with the intercultural experiences acquired in Portuguese language writing classes in the Hawalò village of the Karajá ethnic group. We then reflect on the need to teach writing in Portuguese and how this knowledge must be accompanied by intercultural practices that also guarantee awareness of the importance of the mother tongue.

KEYWORDS: Writing in Portuguese. Karajá/Iny language. Intercultural teaching.

\section{Apresentação}

Pretendo, neste pequeno texto, colocar algumas reflexões importantes sobre o ensino da língua portuguesa na minha escola. Sou professor e, atualmente, estou dando aulas de redação, o que é um grande desafio para mim, mas, ao mesmo tempo, uma grande

1 Licenciado no Curso de "Educação Intercultural" (Ciências da Cultura) pela Universidade Federal de Goiás e Especialista mayem "Educação Intercultural e Transdisciplinar: Gestão Pedagógica", pela mesma Universidade. Professor da Educação Básica. Escola Indígena Malua. Pesquisador da Ação "Saberes Indígenas na Escola", Rede UFG/UFT/UFMA. Aldeia Hawalò, TO, Brasil.E-mail: mn4dj3_kd@hotmail.com. 
aprendizagem. A metodologia que uso nas minhas aulas é sempre considerar o que o aluno e a aluna sabem. É importante considerar o que todos e todas conhecem. Assim, começo a debater as formas de como se pode fazer uma redação em língua portuguesa. Começo sempre de algo bem conhecido, como, por exemplo, sobre as frutas, o rio Araguaia, a convivência com os não indígenas. Deixo que eles e elas façam o texto primeiro na oralidade, só depois na escrita. As redações podem ser pequenas, depois vão ficando maiores. Assim, os alunos e alunas vão perdendo o medo. Vão ficando motivados a escreverem em língua portuguesa.

\section{Considerações sobre a língua portuguesa para os Karajá}

A cultura da língua portuguesa, tanto oral quanto escrita, é para a população indígena no Brasil um grande desafio. Essa língua é economicamente forte, politicamente também. É a língua do poder brasileiro. Nós, indígenas, temos a obrigação de aprender a nos comunicarmos nessa língua. Sem isso, não conseguimos trocar conhecimento. Não conseguimos ter acesso a conhecimentos necessários para nossos líderes, que nos defendem. Precisamos do português para nossa defesa e, também, para conhecermos nossos direitos dentro da legislatura do nosso país.

Uma parte importante que deve ser colocada nas aulas de língua portuguesa é o valor cultural da nossa língua Karajá. Não podemos deixá-la de lado. Temos que mostrar para nossos alunos e alunas, o valor da nossa língua, mesmo nas aulas de língua portuguesa. Queremos fortalecer sempre a nossa língua materna, tanto na oralidade quanto na escrita. Pensar essa dinâmica é importante para a vida da língua. Toda língua muda ou, como afirma Pimentel da Silva (2009), muda para ganhar novas palavras, enunciados, belezas semânticas, mas pode mudar quando vai perdendo função e se enchendo da língua portuguesa, até ser extinta. Tudo isso deve ser discutido nas aulas de língua portuguesa. Nessas aulas, podemos atender as demandas dos estudantes, mas a política comunitária é de manutenção da língua materna.

Onde vivo, em Hawalò, situada na Ilha do Bananal, estado do Tocantins, a língua majoritariamente falada na comunidade é a língua Karajá. Mas, existe uma parte minoritária praticante de outras línguas, como a portuguesa e outras línguas indígenas. Normalmente, 
esta é a situação de comunicação com os indígenas de outros povos que moram na aldeia citada.

Os Karajá têm oportunidade de aprender a falar as duas línguas, a língua materna e o português. Então, o cenário de ensino do português na escola é sempre de bilinguismo. Nesta realidade, temos que considerar alguns aspectos: que a primeira língua do aluno é a Karajá, iniciar a redação em português primeiro na oralidade, a redação deve ser de temas conhecidos primeiro, só depois de outros temas. Assim feito, poderei desafiar os/as estudantes. Ampliar os temas da redação com assuntos que eles precisam pesquisar, fazer leitura, buscar conhecimentos novos para escrever. É preciso formar os estudantes com formação política, mas também para manter nossos valores culturais. Manter nossos saberes. Nisto está a importância da educação intercultural.

O conhecimento do letramento e da escritura promovida dentro do mundo escolar precisa seguir sempre prestando atenção nos dois mundos. Formar nossos jovens para escrever em língua portuguesa, mas também para registrar o conhecimento e saber do próprio mundo Iny. Para redigir em língua portuguesa, acompanhando a complexidade do mundo que ela nomeia em termos políticos, econômicos e científicos. É importante que os estudantes compreendam essas diferentes narrativas. Aprendam os registros que essa língua traz; que façam dissertações de temas diversos; que aprendam a argumentar, uma linguagem de defesa e de justificativa de grande valor para nós, ensinar nossos jovens, pois alguns deles serão líderes em nossa comunidade.

A nossa necessidade tão imensa para aprender a escritura e o letramento da língua portuguesa é real, mas devemos ser cuidadosos para que, em nome dessa necessidade, não deixemos a nossa língua de lado. É verdade que o domínio da escritura da língua portuguesa nos dá uma independência política. Mas, a nossa língua é a nossa raiz, nosso maior patrimônio. Não somos nada sem ela.

Aprendendo a complexidade da língua portuguesa, podemos registrar o mundo do branco, ler seus códigos, de modo independente. Com isso, aprendermos a elaborar nossa gramática da língua Karajá, a criar nosso dicionário, a termos nossa enciclopédia do nosso saber. Aprendemos muito dessas coisas, com a abertura das universidades para população indígena, por meio das cotas e da licenciatura indígena e da Ação "Saberes Indígenas na Escola". 
A partir deste momento histórico, nós indígenas passamos a ser protagonistas do registro dos nossos próprios saberes e temos importância na lei como 11645 e no programa Saberes Indígenas. Penso que esses são exemplos de letramentos interculturais, que podem acontecer em português e na língua materna.

\section{Referências Bibliográficas}

PIMENTEL DA SILVA, M. S. Reflexões sociolinguísticas sobre línguas indígenas ameaçadas. Goiânia: Editora da UCG, 2009.

Recebido para publicação em abril de 2018. Aceito para publicação em junho de 2018. 